\title{
Breeding and testing single-cross maize hybrid QT55 in provinces in the North, South Central and Central Highlands of Vietnam
}

\author{
Le Quy Tuong ${ }^{1}$, Le Van Ninh ${ }^{2}$, Nguyen Tuan $\mathrm{Khoi}^{3}$, Le Quy Tung ${ }^{4}$ and Bui \\ Bao Thinh ${ }^{5 *}$
}

\author{
${ }^{1}$ Center for plant evaluation and seed testing and plant products in Vietnam, Hanoi, Vietnam \\ ${ }^{2}$ Faculty of Agriculture, Forestry and Fishery, Hong Duc University, Thanh Hoa, Vietnam \\ ${ }^{3}$ Faculty of Agronomy, Bacgiang Agriculture and Forestry University, Bac Giang, Vietnam \\ ${ }^{4}$ Faculty of Agronomy, Vietnam National University of Agriculture, Hanoi, Vietnam \\ ${ }^{5}$ School of Natural Sciences, Far Eastern Federal University, Vladivostok, Russia \\ *Corresponding author: bbt.9895@gmail.com
}

\begin{abstract}
In many places around the world, population growth and climate change have been posing huge challenges to agriculture. There are increasing demands for food products in both quantity and quality. As a result, it is essential to develop new hybrid maize varieties with high yield, quality and resistance. In this study, single-cross maize hybrid QT55 was created from a combination of two maize hybrids (D4 x D54). This hybrid maize was tested in some provinces in the North, South Central and Central Highlands of Vietnam. Study results show that in comparison with control maize cultivars, QT55 was a medium early single-cross maize hybrid (medium growth time) with the yields from 69.44 to 75.38 quintals $h^{-1}$ and ranged from 60 to 100.2 quintals $h^{-1}$ during intensive farming. Additionally, QT55 demonstrated higher resistance to stalk borer and other diseases such as the banded leaf, sheath blight and stalk rot. It is less likely to fall, cold tolerant and drought tolerant are better. Single-cross maize hybrid QT55 was best planted in Spring and Autumn-Winter crops (in Northern provinces) and Winter-Spring, SummerAutumn crops (in South Central and Central Highlands).
\end{abstract}

Keywords - single-cross maize hybrid QT55, breeding, testing, medium early, high yield, drought tolerance.

\section{INTRODUCTION}

Maize (Zea mays L.) is one of the important cereal crops, ranking second after wheat based on production (Hallauer and Carena, 2009; Dowswell, 2019). Maize plays a significant role in providing human foods, animal feed, the raw material for the processing industry and biofuels (Shiferaw et al., 2011; Hochman and Zilberman, 2018; Loy and Lundy, 2019). The crop contains a huge amount of cellulose, vitamins, minerals and antioxidants (Ai and Jane, 2016). It does not only provide essential nutrients for human health but also contributes to preventing cancers (Jayaram et al., 2015). In addition, maize is easily cultivated under various climatic conditions, offering great financial support to farmer households (Becerril and Abdulai, 2010; Mathenge et al., 2014). As a result, maize has been widely cultivated in many countries around the world.

In Vietnam, maize has been cultivated in seven agroecological regions. In 2018, the cultivated area of maize in Vietnam was recorded to reach 1039 thousand hectares with the mean yield of 47.2 quintals $\mathrm{ha}^{-1}$ and the output of
4905.9 thousand tons (General Statistics Office of Vietnam, 2018). However, maize cultivation in Vietnam has still failed to meet the domestic consumption demand, leading to annual import of millions of tons of maize for animal feed processing. Statistics show that 10.18 million tons of maize were imported into Vietnam in 2018 (Ministry of Industry and Trade of the Socialist Republic of Vietnam, 2018).

Provinces in the North, South Central and Central Highlands of Vietnam are agriculture-oriented, in which maize is an important crop. The constraints and challenges in maize cultivation faced by farmer households in these regions are mainly the cultivation in riparian zones, narrow areas, medium-qualified and poorly fertile soil, mostly drought soil with water deficiency happening in $70 \%$ of the total cultivated area. The majority of currently cultivated maize varieties are imported hybrid maize cultivars (accounting for over $60 \%$ ) at high prices. Farmer households can hardly take control of the crop seeds. There is a lack of high-qualified medium early hybrid maize cultivars through domestic 
seeding selection as well as suitable cultivation techniques for each cultivar, leading to the fact that some maize cultivars are suffering from pests and diseases at the serious rate and tending to have degenerated. This is also one of the main reasons why Vietnamese commercial maize production is less competitive than that of other countries in the world. Under the pressure of rapid population growth and urbanization, the cultivation area has been decreasing (Wang, 2019). Therefore, the demand for maize can be met when crop yield improves. Additionally, climate change also adversely affects crop growth and development (Calzadilla et al., 2013). Development of new hybrid maize varieties with high yield, high quality and good resistance is a common and inevitable trend of the world (Dass et al., 2009; Schroeder et al., 2013; Abate et al., 2015). This study, therefore, focuses on breeding a new hybrid maize with medium length of growing time, high and stable yield, high resistance to pests and diseases, less likelihood to fall, good drought stress tolerance, which can be suitably planted in major crops of provinces in the North, South Central and Central Highlands of Vietnam.

\section{MATERIALS AND METHODS}

\subsection{Research materials}

Single-cross maize hybrid QT55 was created from the hybrid combination D4 (III115144) x D54 (BOD22). The maternal line D4 (III115144) is originated from tropical region and selected as pour line by self-pollination method. Paternal line D54 (BOD22) is originated from tropical region and selected as pour line by selfpollination method.

Control cultivars: DK9001, CP.333, DK6919, CP888 (basic testing); DK9001, CP888, LVN10, LVN99, CP999, NK67 (production testing); D1, LCH9 (drought experiment). These control varieties are widely cultivated in localities where experiments were carried out.

\subsection{Research venue and time}

Tests of self-pollination, maintenance and evaluation of combining abilities among maize lines were conducted at the Center for plant evaluation and seed testing and plant products in $\mathrm{Tu}$ Liem, Hanoi. Breeder testing was conducted in Thanh Hoa, Vinh Phuc and Binh Dinh. Basic testing in Hanoi, Hai Duong, Thai Binh, Vinh Phuc, Bac Giang, Thanh Hoa, Nghe An, Quang Nam, Quang Ngai, Ninh Thuan and Đăk Lăk. Production testing in Son La, Tuyen Quang, Hoa Binh, Phu Tho, Vinh Phuc, Bac Ninh, Thanh Hoa, Nghe An, Binh Dinh and Đăk Lăk. Experiments were carried out from Autumn-Winter crop, 2012 to Spring crop, 2018.
Experiments on drought tolerance of maternal lines (D4), paternal line (D54) and single-cross maize hybrid QT55 were conducted at the Center for plant evaluation and seed testing and plant products in Tu Liem, Hanoi in Spring crop, 2019 (from February 2019 to April 2019).

\subsection{Research methods}

\subsubsection{Conducting self-pollination, maintenance and} evaluating combining abilities among maize lines

Self-pollinated parental lines of QT55 were selected as pure lines by traditional self-fertilization method, together with self-pollination by full-sib, half-sib selection methods.

Evaluation of combining abilities covered general combining ability (GCA) and specific combining ability (SCA) among 8 pure-line maize cultivars in diallel crossing as mentioned in Experimental method 4 by Griffing (1956).

\subsubsection{Testing new hybrid maize cultivar in different ecological regions}

Breeder testing and basic testing of Single-cross maize hybrid QT55 were conducted in accordance with "National technical regulation on testing for Value of Cultivation and Use of Maize varieties" - QCVN 0156:2011/BNNPTNT by Ministry of Agriculture and Rural Development (2011).

Production testing of single-cross maize hybrid QT55 in experimental ecological regions was carried out based on the process of local hybrid maize cultivation in those localities. The experiments were arranged in a sequential manner, not repeated with control cultivars included. The testing area was $1000 \mathrm{~m}^{2} /$ cultivar/location/crop with a plant population density of 57-64 thousand plants ha ${ }^{-1}$ and fertilizer rate of (10 tons of completely decomposed manure or 2 tons of micro-organic fertilizer $+160 \mathrm{~kg} \mathrm{~N}+$ $\left.90 \mathrm{~kg} \mathrm{P}_{2} \mathrm{O}_{5}+110 \mathrm{~kg} \mathrm{~K}_{2} \mathrm{O}\right) \mathrm{ha}^{-1}$.

\subsubsection{Evaluating drought tolerance}

Drought tolerance of maternal lines (D4), paternal lines (D54) and single-cross maize hybrid QT55 were evaluated at the stage of seedlings with 5 - 6 leaves in covered net houses by CIMMYT (1985) method.

\subsection{Statistical analysis}

Combining ability (including GCA and SCA) of maize cultivars was analyzed based on the dry grain yield of hybrid combination thanks to IRRISTAT 5.0/ Linetest/ Dialen 2 software. Yield data gained from breeder testing and basic testing was statistically processed with IRRISTAT 5.0 and Excel 3.2. In production testing, maize was harvested in randomized-block design by 
statistical method, and the mean yield value was calculated with Excel 3.2 software.

\section{RESULTS AND DISCUSSION}

3.1 Conducting self-pollination, maintenance and evaluating combining abilities among maize lines

Analyses of the general combining ability (GCA) (gi) and the variance of specific combining ability (SCA) ( $\sigma$ ${ }^{2}$ sij) among 8 pure lines of maize in 3 diallel cross experiments conducted in 2012 Autumn-Winter crop, 2013 Spring crop and 2013 Autumn-Winter crop in Hoang Hoa, Thanh Hoa, Vietnam are presented in Table 1.

Table 1. Values of GCA (gi) and variance of SCA ( $\sigma^{2}$ sij) among pure lines of maize in 3 diallel cross experiments conducted in Hoang Hoa, Thanh Hoa, Vietnam ${ }^{1}$

\begin{tabular}{|c|c|c|c|}
\hline No. & $\begin{array}{c}\text { Maize } \\
\text { line }\end{array}$ & $\begin{array}{c}\text { General } \\
\text { combining } \\
\text { ability (gi) }\end{array}$ & $\begin{array}{c}\text { Variance of specific } \\
\text { combining ability ( } \sigma^{2} \text { sij) }\end{array}$ \\
\hline 1 & D4 & +10.69 & +12.048 \\
\hline 2 & D6 & +7.26 & +34.503 \\
\hline 3 & D8 & +9.03 & +27.340 \\
\hline 4 & D54 & +18.65 & +49.209 \\
\hline 5 & D100 & +17.63 & +28.809 \\
\hline 6 & D1 & -16.81 & +37.726 \\
\hline 7 & D25 & -22.67 & +83.209 \\
\hline 8 & D61 & -21.76 & +51.205 \\
\hline
\end{tabular}

${ }^{I}$ The mean value gained from 2012 Autumn-Winter crop, 2013 Spring crop and 2013 Autumn-Winter crop.

Maize lines with high value of GCA include D54 (gi: +18.65), D100 (gi: +17.63), followed by D4 (gi: +10.69), D8 (gi: +9.03) and D6 (gi: +7.26).

Maize lines with the highest variance of SCA include D25 ( $\sigma^{2}$ sij: +83.209), D61 $\left(\sigma^{2}\right.$ sij: +51.205$)$ and D54 $\left(\sigma^{2}\right.$ sij: +49.209). Maize lines with medium variance of SCA include D1 $\left(\sigma^{2}\right.$ sij: +37.726), D6 ( $\left.\sigma^{2}{ }_{\text {sij: }}+34.503\right)$, D8 ( $\sigma^{2}$ sij: +27.340$)$ and D4 $\left(\sigma^{2}\right.$ sij: +12.048$)$.

The two pure lines with high value of GCA and high variance of SCA are D4 (gi: +10.69 and $\sigma^{2}$ sij: +12.048) and D54 (gi: +18.65 and $\sigma^{2}$ sij: +49.209 ). This single hybrid combination D4//D54 generates a new single-cross maize hybrid named QT55, which is put to the breeder testing in different ecological regions.

\subsection{Agronomic characteristics of the maternal line} (D4) and paternal line (D54)

Maternal line D4 took 123-125 days to reach harvest (Spring crop), 101-103 days (Autumn-Winter crop), paternal line D54 took 124-126 days (Spring crop), 103105 days (Autumn-Winter crop). The mean plant height of D4 line reached $132.2 \mathrm{~cm}$ with the mean cob insertion height of $79.4 \mathrm{~cm}$, lower than those of D54 line with the mean plant height of $149 \mathrm{~cm}$ and cob insertion height of $86 \mathrm{~cm}$. The cob length of D54 line was $14.6 \mathrm{~cm}$, longer than that of D4 line $(13.1 \mathrm{~cm})$. Both D4 and D54 lines had 12-16 rows per cob; The average dry grain yield of D4 line reached 30.8 quintals $\mathrm{ha}^{-1}$ and that of D54 line was 30 quintals $\mathrm{ha}^{-1}$. Both lines showed good resistance against stalk borer and diseases (banded leaf, sheath blight, stalk rot). The plant bodies of both lines were firm, less likely to fall, drought-resistant (Table 2).

Table 2. Agronomic characteristics of the maternal line (D4) and paternal line (D54) in 2013 Spring crop and 2014 Autumn-Winter crop in Hoang Hoa, Thanh Hoa, Vietnam

\begin{tabular}{|c|l|c|c|}
\hline No. & \multicolumn{1}{|c|}{ Criteria $^{1}$} & $\begin{array}{c}\text { Maternal } \\
\text { line D4 } \\
\text { (III115144) }\end{array}$ & $\begin{array}{c}\text { Paternal } \\
\text { line D54 } \\
\text { (BOD22) }\end{array}$ \\
\hline 1 & Length of growing period (day) & & \\
\hline 1.1 & 2013 Spring crop & & \\
\hline & Sowing to Tasseling & $74-76$ & $75-77$ \\
\hline & Sowing to Physiological Maturity & $123-125$ & $124-126$ \\
\hline 1.2 & 2013 Autumn-Winter crop & & \\
\hline & Sowing to Tasseling & $53-55$ & $55-57$ \\
\hline & Sowing to Physiological Maturity & $101-103$ & $103-105$ \\
\hline 2 & Plant height (cm) & $132.2 \pm 5$ & $149.0 \pm 9$ \\
\hline 3 & Cob insertion height (cm) & $79.4 \pm 2$ & $86.0 \pm 3$ \\
\hline 4 & Cob length(cm) & $13.1 \pm 1$ & $14.6 \pm 2$ \\
\hline 5 & Number of rows per cob & $12-16$ & $12-16$ \\
\hline 6 & Number of grains per row & 22.3 & 21.0 \\
\hline 7 & $1000-$ grain weight (g) & $270.4 \pm 2$ & $279.2 \pm 2$ \\
\hline 8 & Mean yield (quintal ha ${ }^{-1}$ ) & 30.8 & 30.0 \\
\hline 9 & Protein(\%) & 11.90 & 11.32 \\
\hline 10 & Stalk borer (rating scale 1-5) & $1-2$ & 1 \\
\hline 11 & Banded leaf (rating scale 0-5) & $1-2$ & 0 \\
\hline 12 & Sheath blight (\%) & 3 & 5 \\
\hline 13 & Stalk rot (rating scale 1-5) & $1-2$ & $1-2$ \\
\hline 14 & Number of roots collapsed plants $(\%)$ & 3 & 3 \\
\hline 15 & Drought tolerance (rating scale 1-5) & 2 & 1 \\
\hline 1 & Assessed based on QCVN 01-56:2011/BNNPTNT. & \\
\hline
\end{tabular}

\subsection{Breeder testing on single-cross maize hybrid QT55}

In two Spring crops and one Autumn-Winter crop, the yield of QT55 was recorded at the range from 62.4 to 85.1 quintals $\mathrm{ha}^{-1}$, significantly higher than that of the control cultivars DK9901 and CP.333 at the significance level of $95 \%$. The highest yield in Spring crops was in the range from 69.5 to 85.1 quintals $\mathrm{ha}^{-1}$. The mean yield was 75.38 quintals $\mathrm{ha}^{-1}$, surpassing that of the control varieties (DK9901, CP.333) with the difference of 9.66 quintals ha ${ }^{1}$ (Table 3). 
Table 3. Yield of single-cross maize hybrid QT55 in experimental places within Breeder Testing

\begin{tabular}{|c|c|c|c|c|c|}
\hline \multirow[b]{2}{*}{ Crop } & \multirow[b]{2}{*}{ Location } & \multicolumn{2}{|c|}{ Yield (quintal ha-1) } & \multirow{2}{*}{$\begin{array}{l}\text { CV } \\
(\%)\end{array}$} & \multirow[b]{2}{*}{$\mathbf{L S D}_{\mathbf{0 , 0 5}}$} \\
\hline & & QT55 & $\begin{array}{l}\text { DK9901 } \\
\text { (control) }\end{array}$ & & \\
\hline \multirow{2}{*}{$\begin{array}{c}2013 \\
\text { Autumn } \\
\text {-Winter }\end{array}$} & $\begin{array}{l}\text { Hoang Hoa, } \\
\text { Thanh Hoa }\end{array}$ & 64.0 & 57.8 & 6.0 & 6.3 \\
\hline & $\begin{array}{l}\text { Binh Xuyen, } \\
\text { Vinh Phuc }\end{array}$ & 62.4 & 56.2 & 7.8 & 4.8 \\
\hline \multirow{2}{*}{$\begin{array}{c}2014 \\
\text { Spring }\end{array}$} & $\begin{array}{l}\text { Hoang Hoa, } \\
\text { Thanh Hoa }\end{array}$ & 69.5 & 64.2 & 8.2 & 4.9 \\
\hline & $\begin{array}{l}\text { An Nhon, } \\
\text { Binh Dinh }\end{array}$ & 85.1 & 72.0 & 8.0 & 10.5 \\
\hline \multirow{4}{*}{$\begin{array}{c}2017 \\
\text { Spring }\end{array}$} & $\begin{array}{l}\text { Hoang Hoa, } \\
\text { Thanh Hoa }\end{array}$ & 81.9 & $67.1^{*}$ & 7.4 & 3.5 \\
\hline & $\begin{array}{l}\text { Thieu Hoa, } \\
\text { Thanh Hoa }\end{array}$ & 82.1 & 73.2 & 5.8 & 2.6 \\
\hline & $\begin{array}{l}\text { Cam Thuy, } \\
\text { Thanh Hoa }\end{array}$ & 82.7 & 69.6 & 6.8 & 4.2 \\
\hline & Mean value & 75.38 & 65.72 & & \\
\hline
\end{tabular}

Note: (*) CP.333.

\subsection{Basic testing on single-cross maize hybrid QT55}

\subsubsection{Agronomic characteristics of single-cross maize hybrid QT55}

QT55 is a medium early cultivar, similar to DK9901 line. They took 118-120 days to reach harvest in Spring crop and 108-110 days in Autumn-Winter crop (The Red River Delta - Northern midland and mountainous region), 111-113 days in Autumn-Winter crop and 117-119 days in Spring crop (North Central of Vietnam), 102-104 days in Winter-Spring crop and 95-96 days in SummerAutumn crop (South Central of Vietnam), 95-96 days in Summer-Autumn crop and 115-117 days in WinterSpring crop (Central Highlands of Vietnam). QT55 plant height varied from 176.3 to $231.3 \mathrm{~cm}$, with the mean plant height of $203.8 \mathrm{~cm}$, which was $5.4 \mathrm{~cm}$ higher than that of the control cultivar DK9901. The cob insertion height ranged from 76.9 to $131.7 \mathrm{~cm}$, surpassing that of cultivar DK9901 with the average difference of $6.4 \mathrm{~cm}$. The cob length was recorded at the range from 17.6 to $18.9 \mathrm{~cm}$, and the mean cob length, which was $1.6 \mathrm{~cm}$ longer than that of cultivar DK9901, reached $18.2 \mathrm{~cm}$. QT55 line had from 12 to 18 rows per cob with the mean number of 15 rows per cob, higher than those of control cultivar DK9901 (12-16 rows per cob with the mean number of 13.6 rows per cob). The average 1000-grain weight of QT55 was 306.5 grams and higher than that of the control cultivar DK9901 (270.8 grams). The grain percentage per cob in QT55 was from $54.3 \%$ to $81.3 \%$ with the mean value of $67.8 \%$, roughly equivalent to that of cultivar DK9901 (67.5\%) (Table 4).
Table 4. Some agronomic characteristics of QT55 in experimental places within basic testing

\begin{tabular}{|c|c|c|c|}
\hline \multirow[b]{2}{*}{ No. } & \multirow[b]{2}{*}{ Criteria $^{1}$} & \multicolumn{2}{|c|}{ Variety } \\
\hline & & QT55 & $\begin{array}{l}\text { DK9901 } \\
\text { (control) }\end{array}$ \\
\hline 1 & Length of growing period (day) & & \\
\hline & $\begin{array}{l}\text { - Red River Delta - Northern } \\
\text { midland and mountainous region }\end{array}$ & & \\
\hline & 2015 Spring crop & $118-120$ & $115-117$ \\
\hline & 2015 Autumn-Winter crop & $108-110$ & $105-107$ \\
\hline & - North Central & & \\
\hline & 2017 Autumn-Winter crop & $111-113$ & $109-111$ \\
\hline & 2018 Spring crop & $117-119$ & $117-119$ \\
\hline & - South Central & & \\
\hline & 2015-2016 Winter-Spring crop & $102-104$ & $100-103$ \\
\hline & 2016 Summer-Autumn crop & $95-96$ & $95-97$ \\
\hline & - Central Highlands & & \\
\hline & 2015 Summer-Autumn crop & $95-96$ & $94-96$ \\
\hline & 2015-2016 Winter-Spring crop & $115-117$ & $113-115$ \\
\hline 2 & Plant height $(\mathrm{cm})$ & $203.8 \pm 27.5$ & $198.4 \pm 24.1$ \\
\hline 3 & Cob insertion height $(\mathrm{cm})$ & $104.3 \pm 27.4$ & $97.9 \pm 19.1$ \\
\hline 4 & Cob length $(\mathrm{cm})$ & $18.2 \pm 0.65$ & $16.6 \pm 0.85$ \\
\hline 5 & Number of rows per cob & $12-18$ & $12-16$ \\
\hline 6 & Number of grains per row & $34.4 \pm 3.1$ & $36.2 \pm 2.2$ \\
\hline 7 & 1000-grain weight (gam) & $306.5 \pm 5.5$ & $270.8 \pm 3.5$ \\
\hline 8 & Gain percentage per cob (\%) & $67.8 \pm 13.5$ & $67.5 \pm 14.7$ \\
\hline
\end{tabular}

${ }^{1}$ Assessed based on QCVN 01-56:2011/BNNPTNT.

Sources: Center for plant evaluation and seed testing and plant products in Vietnam, Center for plant evaluation and seed testing and plant products in Central Vietnam, Center for plant evaluation and seed testing and plant products in Highlands Vietnam.

Table 5. Pest and disease tolerance and resistance to unfavorable conditions of QT55*

\begin{tabular}{|c|l|c|c|}
\hline \multirow{2}{*}{ No. } & \multicolumn{1}{|c|}{ Criteria $^{1}$} & \multicolumn{2}{|c|}{ Variety } \\
\cline { 3 - 4 } & & QT55 & $\begin{array}{c}\text { DK9901 } \\
\text { (control) }\end{array}$ \\
\hline 1 & Stalk borer (rating scale 1-5) & $1-2$ & $1-2$ \\
\hline 2 & Corn earworm (rating scale 1-5) & $1-2$ & $1-3$ \\
\hline 3 & Corn leaf aphid (rating scale 1-5) & 1 & $1-3$ \\
\hline 4 & Sheath blight (\%) & 9.5 & 7.4 \\
\hline 5 & Banded leaf (rating scale 1-5) & $0-2$ & $0-3$ \\
\hline 6 & Stalk rot (\%) & 0 & 0 \\
\hline 7 & Number of roots collapsed plants (\%) & 8.8 & 3.4 \\
\hline 8 & Number of stem broken plants (\%) & 1 & 1 \\
\hline 9 & Drought tolerance (rating scale 1-5) & 1 & 1 \\
\hline 10 & Cold tolerance (rating scale 1-5) & $1-2$ & 1 \\
\hline
\end{tabular}

*Mean values were taken from basic testing.

${ }^{1}$ Assessed based on QCVN 01-56:2011/BNNPTNT.

Sources: Center for plant evaluation and seed testing and plant products in Vietnam, Center for plant evaluation and seed testing and plant products in Central Vietnam, Center for plant evaluation and seed testing and plant products in Highlands Vietnam. 
3.4.2 Pest and disease tolerance of single-cross maize hybrid QT55

Table 5 shows that QT55 was rarely infected with the stalk borer (rating scale 1-2), corn earworm (rating scale 1-2) and corn leaf aphid (1 point). The same results were found in testing on DK9901. QT55 was seldom infected with banded leaf (rating scale 0-2) as well as sheath blight (9.5\%); stalk rot was not detected in QT55 (0 points). The corn stalk was strong and good at anti-falling $(8.8 \%$ of the number of roots collapsed plants and $1 \%$ of the number of stem broken plants); fairly drought tolerant and which was cold-resistant, equivalent to DK9901.

\subsubsection{Yield of single-cross maize hybrid QT55}

The yield of single-cross maize hybrid after basic testing conducted in the Red River Delta and Northern midland and Mountainous region was presented in Table 6. In 2014 Winter crop, the yield of QT55 in 3 testing locations ranged from 48.55 quintals $\mathrm{ha}^{-1}$ to 84.22 quintals ha ${ }^{-1}$. The average number was 63.55 quintals ha- ${ }^{-1}$, which was higher than the one of DK9901 at 2.77 quintals ha ${ }^{-1}(4.6 \%)$. In 2015 Spring crop, the yield of QT55 in 4 testing locations ranged from 58.50 to 82.73 quintals ha ${ }^{-1}$, the average number (68.71 quintals $\mathrm{ha}^{-1}$ ) was higher than the figure of DK9901, which reached only 1.56 quintals $\mathrm{ha}^{-1}(2.3 \%)$. In 2015 Winter crop, the yield of QT55 recorded in 5 testing locations ranged from 50.42 to 67.27 quintals ha $^{-1}$ with an average of 59.72 quintals ha $^{-1}$, which was similar to the ones found in DK9901 (60.23 quintals ha $\left.{ }^{-1}\right)$. After 3 basic testing cases in the Red River Delta and Northern midland and mountainous region, QT55 had average yield at 63.67 quintals $\mathrm{ha}^{-1}$, which was $1.6 \%$ higher than the results recorded in the control variety, DK9901.

The yield of single-cross maize hybrid after basic testing conducted in the North Central of Vietnam was showed in Table 6. In 2014 Winter crop, the yield of QT55 in 2 testing locations ranged from 59.87 to 63.72 quintals $\mathrm{ha}^{-1}$. The average number was 61.79 quintals $\mathrm{ha}^{-1}$, which was higher than the one of DK9901 at 0.91 quintals $\mathrm{ha}^{-1}(1.5 \%)$. In 2015 Spring crop, the yield of QT55 in 2 testing locations ranged from 60.95 to 67.87 quintals ha ${ }^{-1}$, the average number (64.91 quintals ha ${ }^{-1}$ ) was 1.85 quintals ha ${ }^{-1}$ higher than the figure of DK9901 ( $2.9 \%$ higher). In 2017 Winter crop, the yield of QT55 recorded in 2 testing locations ranged from 56.82 to 58.80 quintals ha ${ }^{-1}$ with an average of 57.81 quintals $\mathrm{ha}^{-1}$, which was 2.48 quintals $\mathrm{ha}^{-1}$ higher than the ones found in DK9901 (4.5\%). In 2018 Spring crop, the yield of QT55 in 2 testing locations was from 62.83 to 71.29 quintals ha 1 with the average of 67.06 quintals $\mathrm{ha}^{-1}$, which was similar to the ones of DK6919 (68.13 quintals ha $\left.{ }^{-1}\right)$. After 4 basic testing cases in the North Central of Vietnam, QT55 achieved average yield at 62.89 quintals ha ${ }^{-1}$, which was $1.7 \%$ higher than the results recorded in the control varieties $\left(\sim 1.04\right.$ quintals $\left.\mathrm{ha}^{-1}\right)$.

Table 6. Yield of QT55 in basic testing locations in different ecological regions in Vietnam

\begin{tabular}{|c|c|c|c|c|c|}
\hline \multirow[b]{2}{*}{ Crop } & \multirow[b]{2}{*}{ Location } & \multicolumn{2}{|c|}{ Yield (quintal ha ${ }^{-1}$ ) } & \multirow[b]{2}{*}{ CV $(\%)$} & \multirow[b]{2}{*}{$\mathbf{L S D}_{0.05}$} \\
\hline & & QT55 & $\begin{array}{l}\text { DK9901 } \\
\text { (control) }\end{array}$ & & \\
\hline \multicolumn{6}{|c|}{ Red River Delta-Northern midland and mountainous region of Vietnam } \\
\hline \multirow{3}{*}{2014 Winter } & Ha Noi & 57.87 & 56.87 & 5.0 & 4.53 \\
\hline & Hai Duong & 48.55 & 59.79 & 11.6 & 10.87 \\
\hline & Thai Binh & 84.22 & 65.69 & 7.4 & 8.59 \\
\hline \multirow{4}{*}{2015 Spring } & Ha Noi & 58.50 & 65.40 & 8.4 & 9.12 \\
\hline & Hai Duong & 72.86 & 75.19 & 5.5 & 6.98 \\
\hline & Thai Binh & 82.73 & 67.71 & 9.7 & 11.9 \\
\hline & Vinh Phuc & 60.76 & 60.33 & 4.9 & 4.83 \\
\hline \multirow{5}{*}{2015 Winter } & Ha Noi & 63.39 & 58.71 & 5.6 & 5.66 \\
\hline & Hai Duong & 52.31 & 58.95 & 5.0 & 4.78 \\
\hline & Thai Binh & 65.23 & 65.19 & 6.7 & 7.41 \\
\hline & Vinh Phuc & 50.42 & 51.92 & 4.8 & 4.48 \\
\hline & Bac Giang & 67.27 & 66.42 & 9.6 & 10.63 \\
\hline \multicolumn{2}{|c|}{ Mean value } & 63.67 & 62.68 & & \\
\hline \multicolumn{6}{|c|}{ North Central of Vietnam } \\
\hline \multirow{2}{*}{2014 Winter } & Thanh Hoa & 59.87 & 57.80 & 4.1 & 4.26 \\
\hline & Nghe An & 63.72 & 63.97 & 6.1 & 6.81 \\
\hline \multirow{2}{*}{2015 Spring } & Thanh Hoa & 68.87 & 73.17 & 9.1 & 10.49 \\
\hline & Nghe An & 60.95 & 52.95 & 6.5 & 6.16 \\
\hline
\end{tabular}




\begin{tabular}{|c|c|c|c|c|c|}
\hline \multirow{2}{*}{2017 Winter } & Thanh Hoa & 58.80 & 55.10 & 3.6 & 3.01 \\
\hline & Nghe An & 56.82 & 55.57 & 4.5 & 5.03 \\
\hline \multirow{2}{*}{2018 Spring } & Thanh Hoa & 62.83 & $60.00 *$ & 4.0 & 4.70 \\
\hline & Nghe An & 71.29 & $76.25 *$ & 5.0 & 8.75 \\
\hline \multicolumn{2}{|c|}{ Mean value } & 62.89 & 61.85 & & \\
\hline \multicolumn{6}{|l|}{ South Cetral of Vietnam } \\
\hline \multirow{3}{*}{ 2014-2015 Winter-Spring } & Quang Nam & 78.2 & $71.7 * *$ & 4.3 & 5.51 \\
\hline & Quang Ngai & 82.6 & $84.3 * *$ & 5.6 & 7.78 \\
\hline & Ninh Thuan & 68.4 & $65.5 * *$ & 6.2 & 7.12 \\
\hline \multirow{3}{*}{2015 Summer-Autumn } & Quang Nam & 54.5 & $53.5 * *$ & 3.9 & 3.85 \\
\hline & Quang Ngai & 80.3 & $82.9 * *$ & 6.6 & 8.42 \\
\hline & Ninh Thuan & 61.1 & $73.5 * *$ & 5.7 & 6.75 \\
\hline \multirow{3}{*}{ 2015-2016 Winter-Spring } & Quang Nam & 65.1 & $73.1 * *$ & 3.6 & 4.65 \\
\hline & Quang Ngai & 84.5 & $75.8 * *$ & 4.8 & 6.90 \\
\hline & Ninh Thuan & 60.6 & $62.2 * *$ & 7.4 & 7.96 \\
\hline \multicolumn{2}{|c|}{ Mean value } & 70.58 & 71.38 & & \\
\hline \multicolumn{6}{|c|}{ Central Highlands of Vietnam } \\
\hline \multirow{3}{*}{2015 Summer-Autumn } & Buon Ma Thuot & 84.01 & $80.30 * * *$ & 4.3 & 5.83 \\
\hline & Krông Păk & 74.97 & $73.90 * * *$ & 6.7 & 8.54 \\
\hline & Krông Bông & 80.76 & $79.12 * * *$ & 5.7 & 7.86 \\
\hline 2015 Autumn-Winter & Buon Ma Thuot & 80.32 & $80.14 * * *$ & 3.9 & 5.71 \\
\hline 2015-2016 Winter-Spring & Buon Ma Thuot & 83.04 & $75.90 * * *$ & 5.3 & 7.89 \\
\hline \multicolumn{2}{|c|}{ Mean value } & 80.62 & 77.87 & & \\
\hline \multicolumn{2}{|c|}{ Mean value of 5 regions } & 69.44 & 68.44 & & \\
\hline
\end{tabular}

Note: (*) DK6919; (**) CP.333; (***) CP888.

Sources: Center for plant evaluation and seed testing and plant products in Vietnam.

Table 6 depicts the yield of QT55 after basic testing in South Central of Vietnam. In 2014-2015 Winter-Spring crop, the yield of QT55 in 3 testing locations ranged from 68.40 quintals ha ${ }^{-1}$ to 82.60 quintals $\mathrm{ha}^{-1}$. The average number was 76.40 quintals $\mathrm{ha}^{-1}$, which was higher than the one of CP.333 at 2.60 quintals ha ${ }^{-1}(1.5 \%)$. In 2015 Summer-Autumn crop, the yield of QT55 in 3 testing locations ranged from 54.4 to 80.30 quintals $\mathrm{ha}^{-1}$, the average number (65.3 quintals $\mathrm{ha}^{-1}$ ) was lower than the figure of CP.333 at 4.66 quintals $\mathrm{ha}^{-1}$. In 2017 WinterSpring crop, the yield of QT55 recorded in 3 testing locations ranged from 60.6 to 84.5 quintals ha $^{-1}$ with an average of 70.06 quintals ha ${ }^{-1}$, which was similar to the ones of CP.333 (70.36 quintals ha ${ }^{-1}$ ). After 3 basic testing cases in the South Central of Vietnam, QT55 achieved an average yield at 70.58 quintals $\mathrm{ha}^{-1}$, which was nearly the same as the results recorded in CP.333 (71.38 quintals ha $1)$.

The yield of QT55 after basic testing in Central Highlands is also described in Table 6. In 2015 SummerAutumn crop, the yield of QT55 in 3 testing locations ranged from 74.97 to 84.01 quintals $\mathrm{ha}^{-1}$, the average number (79.91 quintals ha ${ }^{-1}$ ) was 2.14 quintals ha ${ }^{-1}$ higher than the figure of CP888 (2.8\%). In 2015 Autumn-Winter crop, the yield of QT55 reached 80.32 quintals ha ${ }^{-1}$, which was similar to the ones of CP888 (80.14 quintals $\left.\mathrm{ha}^{-1}\right)$. In 2015-2016 Winter-Spring crop, the yield of QT55 was 82.03 quintals $\mathrm{ha}^{-1}$. This yield was 7.14 quintals $\mathrm{ha}^{-1}$ higher than the yield of CP888 (9.4\%). After 3 basic testing cases in Central Highlands, QT55 achieved an average yield at 80.62 quintals $\mathrm{ha}^{-1}$, which was higher than the results recorded in CP888. The higher amount was 3.16 quintals ha $^{-1}(3.5 \%)$.

\subsection{Production testing on single-cross maize hybrid QT55}

The results of testing on QT55's production in the Red River Delta and Northern midland and mountainous region is shown in Table 7. QT55 had medium length of growing period (which was longer than DK9901 from 2 to 5 days and similar to LVN99). This variety was a healthy plant that was less infected with the stalk borer and corn earworm as well as other diseases such as the banded leaf, sheath blight and stalk rot. The corn stalk was strong and good at anti-falling; fairly drought tolerant and cold resistant. This plant could be grown in various conditions. The yield of QT55 ranged from 60.9 to 72.4 quintals ha ${ }^{-1}$ with an average of 65.46 quintals ha ${ }^{-1}$. This productivity was higher than control varieties including DK9901, LVN99 and LVN10 from 0.8 to $18.9 \%$. 
Table 7 also describes the production testing of QT55 in North Central of Vietnam. It can be seen that QT55 had medium length of growing period (which was longer than DK9901 from 1 to 4 days). The plant grew well, achieved medium height and was able to create earn corn at medium speed. The ears were long and beautiful with yellow and orange and half tough kennels, which were popular among consumers. QT55 was less infected with the stalk borer and corn earworm as well as other diseases such as the banded leaf, sheath blight and stalk rot. The corn stalk was strong and good at anti-falling; fairly drought tolerant and cold resistant. This variety could be grown in various conditions and was the most suitable for main crop during the year such as Spring crop and Autumn-Winter crop as well as different types of soil in North Central of Vietnam. The average yield of QT55 was 76 quintals ha ${ }^{-1}$ (ranging from 60.0 to 100.2 quintals $\mathrm{ha}^{-1}$ ), which was higher than the control variety (DK9901) from 10 to $15.4 \%$.

The production testing of QT55 in South Central of Vietnam is presented in Table 7. This variety had medium length of growing period (which was longer than DK9901 from 2 to 7 days). The plant grew well, achieved medium height and was able to create earn corn at medium speed. The ears appeared to belong and beautiful with yellow and orange and half tough kennels. The yield of QT55 ranged from 80 to 85.1 quintals ha $^{-1}$ (82.55 quintals ha ${ }^{-1}$ on average), which was higher than the control variety (DK9901) from 10.8 to $18.19 \%$. It was less infected with the stalk borer and corn earworm as well as other diseases such as the banded leaf, sheath blight and stalk rot. The corn stalk was strong and good at anti-falling; fairly drought tolerant and cold resistant. This variety could be grown in various conditions and types of soil. It is suitable for intensive farming.

Table 7. Results of production testing on single-cross maize hybrid QT55 in different ecological regions in Vietnam

\begin{tabular}{|c|c|c|c|c|c|c|}
\hline \multirow[b]{2}{*}{ Crop } & \multirow[b]{2}{*}{ Location } & \multicolumn{2}{|c|}{ Length of growing period (day) } & \multicolumn{2}{|c|}{ Yield (quintal ha ${ }^{-1}$ ) } & \multirow{2}{*}{$\begin{array}{c}\text { Comparing } \\
\text { to control } \\
\text { variety }(\%)\end{array}$} \\
\hline & & QT55 & $\begin{array}{l}\text { DK9901 } \\
\text { (control) }\end{array}$ & QT55 & $\begin{array}{l}\text { DK9901 } \\
\text { (control) }\end{array}$ & \\
\hline \multicolumn{7}{|c|}{ Red River Delta-Northern midland and mountainous region of Vietnam } \\
\hline 2015 Spring & Tam Nong, Phu Tho & 131 & 127 & 60.9 & 54.02 & +12.7 \\
\hline 2015 Spring-Summer & Mai Son, Son La & 114 & $102 *$ & 72.4 & $60.8 *$ & +18.9 \\
\hline 2015 Winter & Tam Duong, Vinh Phuc & 122 & 117 & 62.94 & 58.25 & +8.1 \\
\hline \multirow{2}{*}{2016 Spring } & Son Duong, Tuyen Quang & 110 & $110 * *$ & 67.5 & $61.11 * *$ & +10.4 \\
\hline & Lac Son, Hoa Binh & 120 & 120 & 63.5 & 63.0 & +0.8 \\
\hline \multirow{2}{*}{2016 Winter } & Yen Lac, Vinh Phuc & 116 & 115 & 64.5 & 61.6 & +4.7 \\
\hline & Thanh Thuy, Phu Tho & 118 & 116 & 66.5 & 61.6 & +7.9 \\
\hline \multicolumn{2}{|c|}{ Mean value } & & & 65.46 & 60.05 & +9.0 \\
\hline \multicolumn{7}{|c|}{ North Cetral of Vietnam } \\
\hline 2015 Spring & Yen Thanh, Nghe An & 120 & 116 & 65.2 & 56.9 & +14.5 \\
\hline \multirow{2}{*}{2015 Winter } & Hoang Hoa, Thanh Hoa & 100 & 105 & 60.0 & 54.0 & +11.1 \\
\hline & Yen Thanh, Nghe An & 108 & 110 & 68.5 & 62.0 & +10.5 \\
\hline 2016 Spring & Nghi Loc, Nghe An & 118 & $122 * * *$ & 64.7 & $56.9 * * *$ & +13.7 \\
\hline \multirow{3}{*}{2018 Spring } & Hoang Hoa, Thanh Hoa & 115 & 115 & 90.4 & 79.3 & +14.0 \\
\hline & Thieu Hoa, Thanh Hoa & 119 & 117 & 100.2 & 89.8 & +12.0 \\
\hline & Cam Thuy, Thanh Hoa & 116 & 115 & 83.0 & 75.5 & +10.0 \\
\hline \multicolumn{2}{|c|}{ Mean value } & & & 76.0 & 67.7 & +12.3 \\
\hline \multicolumn{7}{|l|}{ South Cetral of Vietnam } \\
\hline 2013-2014 Winter-Spring & An Nhon, Binh Dinh & 123 & 125 & 85.1 & 72.0 & +18.19 \\
\hline 2014-2015 Winter-Spring & An Nhon, Binh Dinh & 112 & 105 & 80.0 & 72.2 & +10.8 \\
\hline \multicolumn{2}{|c|}{ Mean value } & & & 82.55 & 72.1 & +14.49 \\
\hline \multicolumn{7}{|c|}{ Central Highlands of Vietnam } \\
\hline 2015-2016 Winter-Spring & Eatu, Đăk Lăk & 117 & $115 * * * *$ & 82.85 & $78.12 * * * *$ & +6.1 \\
\hline 2016 Autumn-Winter & Eatu, Đăk Lăk & 110 & $108 * * * * *$ & 73.84 & $70.97 * * * * *$ & +4.0 \\
\hline \multicolumn{2}{|c|}{ Mean value } & & & 78.35 & 74.54 & +5.09 \\
\hline \multicolumn{2}{|c|}{ Mean value of 5 regions } & $100-131$ & $105-127$ & 75.59 & 68.60 & +10.2 \\
\hline
\end{tabular}

Note: (*) LVN10; (**) LVN99; (***) CP999; (****) CP888; (*****) NK67. 
Table 7 depicts the production testing of QT55 in the Central Highlands of Vietnam. It had the same medium length of the growing period as the control varieties (CP888 and NK67). QT55 was less infected with the stalk borer and corn earworm as well as other diseases such as the banded leaf, sheath blight and stalk rot. The corn stalk was strong and good at anti-falling; fairly drought tolerant and cold resistant. The yield was recorded at 78.35 quintals $\mathrm{ha}^{-1}$ on average (ranging from 73.84 to 82.85 quintals $\mathrm{ha}^{-1}$ ). This quantity was $6.1 \%$ and $4 \%$ higher than that of CP888 and NK67 respectively.

In short, production testing of QT55 had been conducted during 13 crops (from 2013-2014 WinterSpring crop to 2018 Spring crop) in 18 different locations of 5 ecological regions including Red River Delta, Northern midland and mountainous region, North Central, South Central and Central Highlands of Vietnam. The yield of dried kennel ranged from 60.0 to 100.2 quintals $\mathrm{ha}^{-1}, 75.59$ quintals $\mathrm{ha}^{-1}$ on average, which was $10.2 \%$ higher than that of control varieties.
3.6 Evaluation drought tolerance of the parental lines and single-cross maize hybrid QT55

3.6.1 Maize growth criteria during drought experiments

Underwater stress during the period from the 3-leaf to 6-leaf stage, QT55 was $39 \mathrm{~cm}$ in height, which was 0.7 cm higher than LCH9 - a drought-tolerant variety; its root length was $49.8 \mathrm{~cm}$, which was $11.5 \mathrm{~cm}$ longer than LCH9; the number of roots found in QT55 is 3 roots less than that of LCH9 (Table 8).

From 3-leaf to 6-leaf stage, D54 (paternal line) was $42.9 \mathrm{~cm}$ in height, which was $12.8 \mathrm{~cm}$ higher than D1; its root length was $51.9 \mathrm{~cm}$ in length, which was $13.2 \mathrm{~cm}$ longer than D1; the number of roots was also higher than that of D1 at 11.2 roots. Meanwhile, D4 (maternal line )' height was $31.7 \mathrm{~cm}$, which was $1.6 \mathrm{~cm}$ higher than D1; its root length was $47.1 \mathrm{~cm}(8.4 \mathrm{~cm}$ higher than D1) and the number of roots was 5.2 (2.9 roots less than D1) (Table 8).

Table 8. Height, root length and the number of roots of QT55 lines/varieties

\begin{tabular}{|c|c|c|c|c|c|c|c|}
\hline \multirow{2}{*}{ No. } & \multirow{2}{*}{$\begin{array}{c}\text { Line/ } \\
\text { variety }\end{array}$} & \multicolumn{2}{|c|}{ Height $\mathbf{( c m )}$} & \multicolumn{2}{c|}{ Root length $(\mathbf{c m})$} & \multicolumn{2}{c|}{ Number of roots (root) } \\
\cline { 3 - 8 } & Watering & $\begin{array}{c}\text { With } \\
\text { watering }\end{array}$ & $\begin{array}{c}\text { Without } \\
\text { watering }\end{array}$ & $\begin{array}{c}\text { With } \\
\text { watering }\end{array}$ & $\begin{array}{c}\text { Without } \\
\text { watering }\end{array}$ & $\begin{array}{c}\text { With } \\
\text { watering }\end{array}$ \\
\hline 1 & D1 & $30.1 \pm 3.8$ & $44.8 \pm 2.6$ & $38.7 \pm 9.6$ & $54.2 \pm 6.5$ & $8.1 \pm 1.7$ & $11.9 \pm 2.2$ \\
\hline 2 & D4 & $31.7 \pm 2.4$ & $35.9 \pm 4.1$ & $47.1 \pm 8.6$ & $55.2 \pm 9.4$ & $5.2 \pm 0.8$ & $7.2 \pm 1.4$ \\
\hline 3 & D54 & $42.9 \pm 4.6$ & $46.7 \pm 9.1$ & $51.9 \pm 10.7$ & $65.9 \pm 12.3$ & $11.2 \pm 2.4$ & $11.8 \pm 3.5$ \\
\hline 4 & QT55 & $39.0 \pm 3.8$ & $47.0 \pm 9.5$ & $49.8 \pm 8.1$ & $57.6 \pm 13.4$ & $8.6 \pm 1.9$ & $11.8 \pm 3.4$ \\
\hline 5 & LCH9 & $38.3 \pm 3.2$ & $46.2 \pm 9.4$ & $38.3 \pm 6.9$ & $78.1 \pm 16.5$ & $11.6 \pm 1.6$ & $8.5 \pm 3.2$ \\
\hline
\end{tabular}

3.6.2 QT55's recovery after re-watering at 5-6-leaf stage

QT55's drought tolerance (rating scale 2-3) was similar to that of the drought-tolerant variety LCH9 (rating scale 2). After wilting at the 6-leaf stage and after 2 days re-watering, QT55 (rating scale 2) had the same recovery after re-watering as LCH9 (rating scale 2) (Table 9).

Table 9. Recovery after re-watering of lines/varieties QT55 at the 5-6-leaf stage

\begin{tabular}{|c|c|c|c|}
\hline No. & Line/variety & $\begin{array}{c}\text { Drought tolerance } \\
\text { (Rating scale 1-5) }\end{array}$ & $\begin{array}{c}\text { Recovery after 2 } \\
\text { days re-watering } \\
\text { (Rating scale 1-5) }\end{array}$ \\
\hline 1 & D1 & $3-4$ & 4 \\
\hline 2 & D4 & $2-3$ & 3 \\
\hline 3 & D54 & 2 & 2 \\
\hline 4 & QT55 & $2-3$ & 2 \\
\hline 5 & LCH9 & 3 & 2 \\
\hline
\end{tabular}

The paternal line, D54 (rating scale 2) was drought tolerant better than D1 (rating scale 3-4). After wilting at 6-leaf stage and after 2 days re-watering, D54 (rating scale 2) was able to recover better than D1 (rating scale 34). The maternal line, D4 (rating scale 2-3) was also better at drought tolerance than D1 (rating scale 3-4). After wilting at 6-leaf stage and after 2 days re-watering, D4 (rating scale 3) showed better performance in recovery than D1 (rating scale 4) (Table 9).

\subsubsection{Weight of dry matter of QT55 lines/ varieties during drought experiments}

Underwater stress from 3-leaf stage to 5-6-leaf stage, QT55's weight of dry matter was 0.510 grams/plant, which was higher than LCH9 (0.419 grams/plant) significance level of $95 \%$ (Table 10). 
Table 10. Weight of dry matter of QT55 lines/varieties during drought experiment in net houses

\begin{tabular}{|c|c|c|c|}
\hline \multirow{2}{*}{ No. } & \multirow{2}{*}{ Line/variety } & \multicolumn{2}{|c|}{$\begin{array}{c}\text { Weight of dry matter } \\
\text { (gram/plant) }\end{array}$} \\
\cline { 3 - 4 } & & $\begin{array}{c}\text { Without } \\
\text { watering }\end{array}$ & $\begin{array}{c}\text { With } \\
\text { watering }\end{array}$ \\
\hline 1 & D1 & 0.167 & 0.351 \\
\hline 2 & D4 & 0.233 & 0.346 \\
\hline 3 & D54 & 0.466 & 0.507 \\
\hline 4 & QT55 & 0.510 & 0.552 \\
\hline 5 & LCH9 & 0.419 & 0.497 \\
\hline & $C V \%$ & 10.2 & 7.5 \\
\hline & $L S D_{0.05}$ & 0.101 & 0.093 \\
\hline
\end{tabular}

At 5-6 leaf stage, the weight of dry matter of paternal line, D54, and the maternal line, D4, was 0.466 grams/plant and 0.233 grams/plant respectively, which were higher than D1 at 0.167 grams/plant with a significance level of $95 \%$ (Table 10).

\section{CONCLUSIONS}

The final result of the study was a single cross maize hybrid, QT55 with medium length of growing period. This variety was $203.8 \mathrm{~cm}$ high on average while the average corn insertion height was $104.3 \mathrm{~cm}$. It was a healthy plant which able to grow well in a good shape, the leaves covered all the cob; the grain percentage per cob was $67.8 \%$; 1000-Grain Weight was 306.5 grams on average. The yields (basic testing) in the Red River Delta and Northern midland and mountainous region, North Central, South Central and Central Highlands of Vietnam were 63.67 quintals $\mathrm{ha}^{-1}, 62.89$ quintals $\mathrm{ha}^{-1}, 70.58$ quintals $\mathrm{ha}^{-1}$ and 80.62 quintals $\mathrm{ha}^{-1}$ respectively. The average yields (production testing) in the Red River Delta and Northern midland and mountainous region reached 65.46 quintals $\mathrm{ha}^{-1}$, which was $9 \%$ higher than the control variety; the figures recorded in North Central, South Central and Central Highlands of Vietnam were 76 quintals ha ${ }^{-1}, 82.55$ quintals $\mathrm{ha}^{-1}$ and 78.35 quintals ha ${ }^{-1}$, which were $12.3 \%, 14.49 \%$ and $5.09 \%$ higher than the control variety respectively. QT55 was fairly good at drought tolerance, less infected with the stalk borer as well as other diseases such as the banded leaf, sheath blight and stalk rot. The variety was also good at antifalling and suitable for different crops in provinces in the North, South Central as well as the Central Highlands of Vietnam.

\section{AUTHOR CONTRIBUTIONS}

LQT (Le Quy Tuong) and LVN conceived the idea and designed the experiments. LQT (Le Quy Tuong),
LVN, LQT (Le Quy Tung) and NTK implemented the experiments. LQT (Le Quy Tuong) and BBT analyzed the research data. LQT (Le Quy Tuong) prepared the draft of the paper. BBT wrote and edited the manuscript. All authors agreed with the final version of the manuscript.

\section{FUNDING}

This research was partially funded by the Thanh Hoa Department of Science and Technology, Vietnam under contract number 949/2017/HĐKHCN-ĐTKHCN.

\section{ACKNOWLEGEMENT}

The authors thank Center for plant evaluation and seed testing and plant products in Vietnam and Hong Duc University, Vietnam for their assistance to this research. The authors would also like to thank all participants in this research.

\section{CONFLICTS OF INTEREST}

The authors declare no conflict of interest.

\section{REFERENCES}

[1] Abate, T., Shiferaw, B., Menkir, A., Wegary, D., Kebede, Y., Tesfaye, K., Kassie, M., Bogale, G., Tadesse, B. and Keno, T. (2015). Factors that transformed maize productivity in Ethiopia. Food Security, 7(5), 965-981.

[2] Ai, Y. and Jane, J. L. (2016). Macronutrients in corn and human nutrition. Comprehensive Reviews in Food Science and Food Safety, 15(3), 581-598.

[3] Becerril, J. and Abdulai, A. (2010). The impact of improved maize varieties on poverty in Mexico: a propensity score-matching approach. World development, 38(7), 1024-1035.

[4] Calzadilla, A., Rehdanz, K., Betts, R., Falloon, P., Wiltshire, A. and Tol, R. S. (2013). Climate change impacts on global agriculture. Climatic change, 120(1-2), 357-374.

[5] CIMMYT. (1985). Managing trials and reporting data for CIMMYT's International Maize Testing Program. Mexico, D.F.

[6] Dass, S., Kaul, J., Manivannan, A., Singode, A. and Chikkappa, G. K. (2009). Single cross hybrid maize-A viable solution in the changing climate scenario. Indian Journal of Genetics and Plant Breeding, 69, 331-334.

[7] Dowswell, C. (2019). Maize in the third world. CRC Press.

[8] General Statistics Office of Vietnam. (2018). Social and economic situation in 2018. Available online: https://www.gso.gov.vn/default_en.aspx?tabid=622\&Item $\underline{\mathrm{ID}=19043}$ (accessed on 15 June 2019).

[9] Griffing B. (1956). Concept of general and specific combining ability in relation to diallel crossing system. Australian journal of biological sciences, 9(4), 463-493.

[10] Hallauer, A. R. and Carena, M. J. (2009). Maize. In Cereals (pp. 3-98). Springer, New York, NY. 
[11] Hochman, G. and Zilberman, D. (2018). Corn ethanol and US biofuel policy 10 years later: A quantitative assessment. American Journal of Agricultural Economics, $\mathbf{1 0 0 ( 2 ) , ~ 5 7 0 - 5 8 4 . ~}$

[12] Jayaram, S., Kapoor, S. and Dharmesh, S. M. (2015). Pectic polysaccharide from corn (Zea mays L.) effectively inhibited multi-step mediated cancer cell growth and metastasis. Chemico-biological interactions, 235, 63-75.

[13] Loy, D. D. and Lundy, E. L. (2019). Nutritional Properties and Feeding Value of Corn and Its Coproducts. In Corn (pp. 633-659). AACC International Press.

[14] Mathenge, M. K., Smale, M. and Olwande, J. (2014). The impacts of hybrid maize seed on the welfare of farming households in Kenya. Food Policy, 44, 262-271.

[15] Ministry of Agriculture and Rural Development of the Socialist Republic of Vietnam. (2011). "National technical regulation on testing for Value of Cultivation and Use of Maize varieties" - QCVN 0156:2011/BNNPTNT. Available online: http://tieuchuan.mard.gov.vn/ViewDetails.aspx?id=5554\& $\underline{\mathrm{v}=1 \& \mathrm{cap}=3}$ (accessed on 15 June 2019).

[16] Ministry of Industry and Trade of the Socialist Republic of Vietnam. (2018). Vietnam Export and Import Report 2018. Available online: https://moit.gov.vn/documents/40266/0/Bao+cao+Xuat+n hap+khau+Viet+Nam+2018.pdf/7f1254e3-a1e3-4e90b050-b8fd9c5b30f0 (accessed on 15 June 2019).

[17] Schroeder, C., Onyango, T. K. O., Nar, R. B., Jick, N. A., Parzies, H. K. and Gemenet, D. C. (2013). Potentials of hybrid maize varieties for small-holder farmers in Kenya: a review based on Swot analysis. African Journal of Food, Agriculture, Nutrition and Development, 13(2), 75627586.

[18] Shiferaw, B., Prasanna, B. M., Hellin, J. and Bänziger, M. (2011). Crops that feed the world 6. Past successes and future challenges to the role played by maize in global food security. Food Security, 3(3), 307-327.

[19] Singh, A. (2015). Soil salinization and waterlogging: A threat to environment and agricultural sustainability. Ecological indicators, 57, 128-130.

[20] Wang, Y. S. (2019). The Challenges and Strategies of Food Security under Rapid Urbanization in China. Sustainability. 11(2), 542. 